15. Lee J.-W., Cho H. G., Moon B.-Y., Kim S.-Y., Yu D.-S. Effects of prolonged continuous computer gaming on physical and ocular symptoms and binocular vision functions in young healthy individuals. Peer J. 2019. Vol. 7. e7050.

16. Li S. M., Li S. Y., Kang M. T., Zhou Y., Li H., Liu L. R., Yang X. Y., Wang Y. P., Yang Z., Zhan S. Y., Gopinath B., Mitchell P., Atchison D. A., Wang N. Distribution of ocular biometry in 7- and 14-year-old Chinese children. Optom Vis Sci. 2015. Vol. 92. P. 566-572.

17. Parssinen O., Lyyra A. L. Myopia and myopic progression among schoolchildren: a three-year follow-up study. Invest Ophthalmol Vis Sci. 1993. Vol. 34. P. 2794-2802.

18. Rose K. A., Morgan I. G., Ip J., Kifley A., Huynh S., Smith W., Mitchell P. Outdoor activity reduces the prevalence of myopia in children. Ophthalmology. 2008. Vol. 115. P. 1279-1285.

19. Wu L. J., You Q. S., Duan J. L., Luo Y. X., Liu L. J., Li X., Gao Q., H. P. Zhu, He Y., Xu L., Jonas J. B., Wang W., Guo X. H. Prevalence and associated factors of myopia in high-school students in Beijing. PLoS One. 2015. Vol. 10. e0120764.

20. Wu P. C., Tsai C. L., Wu H. L., Yang Y .H., Kuo H. K. Outdoor activity during class recess reduces myopia onset and progression in school children. Ophthalmology. 2013. Vol. 120. P. 1080-1085.

DOI https://doi.org/10.30525/978-9934-26-182-4-43

\title{
НУТРИЦІОЛОГІЯ - СКЛАДОВА ПРОГРЕСИВНОГО РОЗВИТКУ ПРОФІЛАКТИЧНОЇ МЕДИЦИНИ
}

\author{
Гнатушко В. П.
}

асистент кафедри пропедевтики внутрішньої медицини Івано-Франківський начіональний медичний університет м. Івано-Франківськ, Украӥна

Здоров'я-це стан фізичного ,духовного та соціального благополуччя, а не тільки відсутність хворіб і фізичних дефектів.

Розвиток захворювань, частіше хронічних, наступає дуже швидко. Запобігти патології можна, профілатика хвороби-вихід цьому.

Що ж таке профілактика-це один із напрямків медицини, який базується на комплексі гігієнічних ,медичних, соціально-економічних та 
санітарно-технічних заходях, спрямованих на усунення факторів ризику, що впливають на здоров'я населення.

Є три види профілактики, а саме : первинна- використовуєтся, щоб не допустити захворюваня, вторинна- спрямована на раннє виявлення лікування хвороби на доклінічній стадії, третинна-заходи ,які спрямовані на попередженя розвитку ускладнень та погіршення перебігу хвороби, а також динамічне спостереження за паціснтами для запобігання виникненню таких наслідків ,як : смерть, інвалідизація.

Нутриціологія - складова прогресивноо розвитку профілактичної медицини, яка застосовує організацію харчування в лікувальнопрофілактичних, оздоровчих установах, а також методи профілактики за допомогою спеціально підібраної дієти.

Сучасний стан профілактичної медицини в Україні на етапі цілісного формування, більше базується на стандартах надання медичної допомоги вже в період сформованої патології,щоб уникнути прогресуванню.

Незбалансоване харчування, не дотримання режиму прийомів їжі, неправильне поєднання продуктів, дефіцит чи надлишок калорій- це все призводить до виникнення розвитку дефіциту мікро та макроелементів, до інсулінорезистентності, ожиріння ,ШД 2 типу, атеросклерозу, дефіциту вітамінів та інших-розвитку хронічних захворювань.

В медичних центрах має бути спеціаліст практичної нутриціології ,який комплексно разом із іншими фахівцями ( ендокринологами, терапевтами ,гінекологами ), зможе провести діагностику, навчальну бесіду, надати професійні рекомендації та націлити пацієнта на профілактику розвитку паталогії. Матеріально-технічне забезпеченняодна із основних умов, посібники, інформаційні брошури - на безоплатному рівні-для більшої можливості розповсюдження інформації.

Висновок: надзвичайно важливо створювати центри профілактики здоров'я, забезпечити в них умови для діяльності фахівців профілактичної медицини: нутриціологів, дієтологів, фізіотерапевтів, гігієністів, які б здійснювали повноцінну пропаганду здорового способу життя, надавали практичну допомогу пацієнтам - це все має бути економічно вигідним для держави.

\section{Література:}

1. Гігієна харчування 3 основами нутриціології/ За ред. проф. B.I. Ципріяна / 2 том., Київ: Медицина, 2007. - 560 с.

2. Essentials of Global Health /https://ru.coursera.org/learn/essentialsglobal-health 